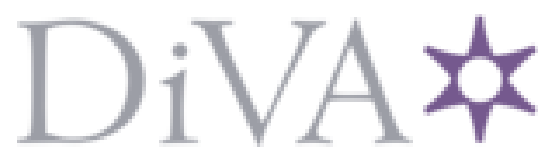

http://www.diva-portal.org

\title{
Postprint
}

This is the accepted version of a paper published in Journal of Organizational Change Management. This paper has been peer-reviewed but does not include the final publisher proof-corrections or journal pagination.

Citation for the original published paper (version of record):

Brunninge, O. (2009)

Using history in organizations: How managers make purposeful reference to history in strategy processes.

Journal of Organizational Change Management, 22(1): 8-26

http://dx.doi.org/10.1108/09534810910933889

Access to the published version may require subscription.

N.B. When citing this work, cite the original published paper.

Permanent link to this version:

http://urn.kb.se/resolve?urn=urn:nbn:se:hj:diva-8093 
Brunninge, O. (2009). Using history in organizations: How managers make purposeful reference to history in strategy processes. Journal of Organizational Change Management, 22(1), 8-26.

\section{Using history in organizations}

How managers make purposeful reference to history in strategy processes

Olof Brunninge, Ph.D.

Jönköping International Business School

P.O Box 1026

SE- 55111 Jönköping

Sweden

Phone +46733826107

Olof.Brunninge@ju.se 


\title{
Using history in organizations
}

How managers make purposeful reference to history in strategy processes

\author{
by Olof Brunninge
}

\begin{abstract}
Purpose - This paper aims to explore how organizational actors make reference to history and how they use historical reference purposefully in order to affect strategy-making.
\end{abstract}

Design/methodology/approach - The paper draws on in-depth case studies on two Swedish MNCs. Data have been collected through 79 interviews as well as participant observation and archival studies.

Findings - Organizational actors purposefully construct and use history in order to establish continuity in strategy processes. The use of historical references legitimizes or delegitimizes specific strategic options.

Research limitations/implications - Two old firms with a clear interest in organizational history have been studied. Future research on additional companies, including young firms and firms with less interest in history, is needed.

Practical implications - The purposeful use of history can be a powerful tool for managers to influence organizational change processes.

Originality/value - Very little research on the use of history in business organizations has so far been done. In an interdisciplinary manner the paper introduces concepts from research in history to management research. Based on two rich case studies the paper contributes by outlining what role different uses of history play in strategic and organizational change.

\section{Introduction}

For a couple of decades, management research has been dominated by cross-sectional, basically ahistorical research (Pettigrew, 1990, 1997). However, in recent years we have witnesses an increasing interest in history among organization theorists (Kieser, 1994), economists (David, 1985) and strategy scholars (Pettigrew, 1990, 1997). Clark and Rowlinson (2004) thus see organization studies in a move towards a "historic turn". Historical analyses are applied to organizations with various aims, such as confirming theories, selecting hypotheses, developing our understanding of contemporary organizations or constructing narratives of historical processes (Kieser, 1994; Üsdiken and Kieser, 2004). This does not yet mean that historical consciousness has come to permeate management research in general. However, there are some promising tendencies to use the potential of historical analyses to better understand organizations and change processes.

Despite an increasing openness to postmodern approaches (Clark and Rowlinson, 2004), most historical studies of organizations still take a basically realist stance. While not denying that historical studies always involve interpretation, they aim at reconstructing history as it actually occurred. Such studies have enriched our knowledge by helping us to learn about the past as well as to theorize based on historical processes (Chandler, 1962; Pettigrew, 1985; Freeland, 2001). While the study of historical processes as such is an exciting and so far underexploited area for management research (Pettigrew, 1990), the question of how organizational members 
relate to the past of their organization has received even less attention. When history is a topic in organization studies, it is often treated as a variable explaining the current state of the organization (Ericson, 2006). The past in itself is seen as an unchangeable fact that does not leave room much room for interpretation. The present paper does not question the value of such research. However, it wants to draw attention to a much neglected aspect of organizational history, namely how contemporary organizational members relate to the history of their organization, make sense of it, talk about it, and sometimes purposefully use it in order to achieve their aims. This topic shifts attention from the question about what is the actual history of the organization to the question what members believe to be the actual history. Such an interpretive conception of history is likely to be important for how people in an organization act and how they go about organizational and strategic change.

Among historians there is a growing steam of research, investigating what history means to contemporary actors and how different communities construct conceptions of the past (Schulze, 1987; Hobsbawm and Ranger, 1992; Nora, 1998). The research on interpretations of history has proven to be helpful in understanding diverse issues such as the formation of collective identities (Zander, 1997; Trenter, 2000), the achievement of political goals (Karlsson, 1999), or the creation of legitimacy for visions of the future (Karlsson, 1999). In organization studies, so far few scholars have addressed how organizational actors refer to the past. Among the notable exceptions are Chreim (2005) work on change management in a Canadian bank, Lundström's (2006) dissertation on the Swedish telecom company Ericsson, and Ericson (2006) study of how a Swedish consumer cooperative deals with its ideological heritage. Despite these important pieces of research we still have very limited knowledge about how conceptions of history are socially constructed in business organizations and in particular what these constructions of history imply for future-oriented strategic action. The present paper thus aims at exploring how organizational actors make reference to history and how they use historical reference purposefully in order to affect strategy-making. Empirically, it draws upon extensive case studies of two large, multinational Swedish firms, the truck maker Scania and the bank Handelsbanken. The remaining parts of this paper are structured as follows: first, I am going to address what views on history prevail in contemporary management research and what an interpretive perspective on history may add to our understanding of management processes. The following part offers a review of research by historians on historical consciousness and the using of history. This research provides a perspective as well as conceptual tools that contribute to understanding how actors in business organizations refer to the past. After these two theoretical parts, a methodology section introduces the empirical study of Scania and Handelsbanken. The paper is rounded off with a discussion of the empirical findings as well as conclusions on the use of history in business organizations.

\section{History in management research}

History is not a new topic to business research and interest in history goes beyond the community of business historians that have the study of the past as their primary focus. Particularly strategy process researchers, with their strong interest in the organizational context of strategy-making, have emphasized the importance of history for understanding strategy processes (Kimberly, 1987; Kimberly and Bouchikhi, 1995; Melin, 1998; Pettigrew, 1990, 1997). The process scholars have criticized mainstream management research for being ahistorical (Pettigrew, 1990) when carrying out cross-sectional studies or relying on a few snapshots to establish longitudinality. As a counter movement, there is a stream of longitudinal case study research, following the development of companies (Pettigrew, 1985; Frankelius, 1999) or entire industries (Melander, 1997) over years and decades. The proponents of this research tradition argue that strategies and their development can only be properly analyzed in their historical context. Not least systems of meaning, like organizational culture and identity, can only be understood through going back in time (Hatch and Schultz, 1997; Normann, 1975; Rhenman, 1973). 
While business historians usually see the reconstruction and interpretation of historical processes as an aim in itself, longitudinal management studies mainly aim at theorizing on management phenomena. This can be done by using historical data as a means to study longer processes or to put present developments into context. The dividing line between business history and longitudinal, partly retrospective management research is not always crystal clear. Chandler's $(1962,1977)$ and more recently Freeland (2001) work on the development of management and industrial companies as well as Kieser $(1987,1989)$ studies of medieval organizing are primarily accounts of large-scale historical developments in business and society. Nevertheless, they also make theoretical contributions that go beyond business history, like Chandler's (1962) ideas on the relationship of strategy and organizational structure or Freeland (2001) criticism of transaction cost theory. On the other hand, longitudinal management research where the main emphasis lies on the development of theoretical concepts, can also contribute to business history, as Melander's $(1997,2005)$ study of the Swedish pulp and paper industry.

As Ericson (2006) points out in a thorough analysis of how the past is addressed in management research, history is primarily seen as an explanation of inertia or path dependencies. Organizations get stuck in historical development paths, limiting the range of strategic options that is open for them. This is for instance the case for the dynamic capabilities view on strategic change (Teece et al., 1997) as well as evolutionary economics (Nelson and Winter, 1982). Such a perspective implies that the past is treated as an independent variable, which can be objectively known and which is fixed forever once it has occurred. Organizations are seen to have a history, in which specific resource configurations (Wernerfelt, 1984; Barney, 1991) a distinctive organizational culture (Rhenman, 1973) and other characteristics originate. These are difficult or even impossible to alter in hindsight. While they may be success factors during long periods of time, they can also turn into sources of strategic inertia that eventually lead to the failure of the organization (Hannan and Freeman, 1977). Such a view of organizational history is deterministic. It implies that if history actually matters to organizations, it constitutes a cage that severely constrains the possibilities for organizational change.

Also classical strategy process studies such as those of Pettigrew (1985) and Johnson (1987) that put much emphasis on history, conceive history in a relatively objectivist manner. While not denying that history can only be known through interpretation, the past is primarily seen as a forerunner of the present that can be known through thorough research. Hence, history is a part of the strategy process that helps understanding the following parts, but once it has occurred, it is practically fixed and cannot be altered. Hence, also in strategy process research there is a strong case for inertia. Johnson (1987) for instance describes how historically embedded paradigms prevent change from occurring. History is particularly important for understanding change or the absence of change in organizations. Discussing change requires a historical perspective as change by definition only can be seen by comparing to different points in time.

Already Selznick (1957) remarked that there are historical restrictions to change. Introducing the concept of institutional integrity, he noted that over time organizations are infused with value for their own sake - they become institutionalized. Institutional integrity is only maintained as long as the organization's basic character remains intact. This does not rule out change per se. However, it implies that organizations do not tolerate change that is disruptive in relation to their basic character or - as we would perhaps say today - their identity (Albert and Whetten, 1985). Selznick's work thus suggests that the development of organizations should not be analyzed as an issue of change or stability, but rather as a question of continuous or discontinuous change. The Oxford English Dictionary defines continuity as "the state or quality of being uninterrupted in sequence or succession, or in essence or idea" (The Oxford English Dictionary, 1989). Hence, continuity does not rule out change. It rather denotes a specific type of change. The change involved in continuity is not necessarily small, but it happens without ruptures that disconnect the new situation from the past. The outcome of change has enough 
similarity with history to be recognized as its continuous follower. The question whether change is regarded as continuous and hence acceptable is again a question relating to organizational history. Does this then mean that history predetermines which changes will be regarded as continuous and which changes will be regarded as discontinuous?

While hardly anyone would argue that organizational history as it has actually occurred can be altered in hindsight, some scholars have recently started emphasizing that organizational history can only be known through interpretation (Lundström, 2006). Members of an organization do not act upon the actual history of their organization, but rather what they believe to be organizational history. These beliefs are socially constructed when organizational members collectively remember the past, discuss it and assign meaning to it. This interpretive perspective opens up for a dynamic view of organizational history and questions the determinism of historical trajectories. If conceptions of history come about through interpretation then eventually also continuity and discontinuity in organizational change are results of interpretation and can be reinterpreted over time. When organizational members reinterpret and assign new meanings to their historical heritage, the implications of the past for present and future challenges also change. This provides managers with the option to actively "use" history in change processes, by giving sense (Gioia and Chittepeddi, 1991) to past events. As Cohen and March (1986) remark, interpreting history is a powerful means of influencing decision-making as organizational members tend to believe in the significance of historical examples as a basis for action. An interpretive view on history thus means that history not necessarily promotes stability, but rather can be a driving force in contemporary change processes. While such a view is still uncommon in organizational studies, there is a growing stream of research among historians that addresses the question how different communities relate to their past and how they collectively shape conceptions of history by interpreting and assigning new meanings to historical processes. In the coming section we will therefore look at what contribution research conducted by historians can make to our understanding of organizational history.

\section{Using history}

Historical research was traditionally dominated by an objectivist paradigm, striving for exploring history as it actually happened, as formulated by the German nineteenth century historian Ranke. Meanwhile historians agree that even seemingly undisputed historical "facts" need to be interpreted and that competing interpretations of the same course of events often exist. This does not imply a totally relativist view on history. Yet the insight that we can only know history through interpretation has created a growing interest in the question how interpretations of history come about and what these interpretations mean in society. A growing stream of thought among historians has been focusing on how people treat and use history (Aronsson, 2004; Zander, 2001 for reviews). Here, the main issue is not what actually has happened during a historical process. Rather, the emphasis lies on the question how historical events are perceived and dealt with. Hobsbawm and Ranger (1992) have for instance investigated how traditions are created. They found that traditions are often younger than they appear and that they are frequently introduced for more or less political reasons. Current ideas are legitimized by depicting them as continuous developments from ancient origins. Schulze (1987) uses the metaphor of history as a quarry, from which appropriate stones are selected and included in an ideological building. Nora (1998) found that human memory often refers to specific events, locations or artifacts - he calls them places of memory - that come to symbolize more comprehensive developments. For example, Auschwitz has come to embody the Holocaust and Nazi atrocities against Jews and other groups in general (Reichel, 2005). As Karlsson (2003) points out, the Holocaust drastically exemplifies that it is meaningful to study historical events from two perspectives:

(1) On the one hand, it is important to examine what has actually occurred.

(2) On the other hand, it is important to understand what a historical event has meant to the coming generations. 
Jensen (1997) claims that people develop a historical consciousness, meaning that they become aware of the processual linkages between past present and future. Drawing upon Jeismann (1979) he defines historical consciousness as "all forms of consciousness that concern [. . .] the interplay between interpretation of the past $\$$ understanding of the present $\$$ expectations for the future" (Jensen, 1997, p. 59, original emphasis). Hence, the question how we interpret our past has consequences for how we understand our present situation and what we expect for the future. However, the relationship also works the other way round, meaning that for instance changing expectations for the future may also shed a new light on what has happened in the past.

The linking of past, present, and future through people's historical consciousness opens up various ways of more or less purposefully relating to history. Karlsson (1999) in this context talks of "using" history. Actors in society make reference to the past for various purposes and thus become "users" of history. The degree of intentionality in using history differs. It may range from remembrance without any conscious purpose to instrumental use of historical references for achieving a specific aim. One can of course, debate to what extent collective conceptions of history are manageable. They are inherently cultural phenomena and as we know form research on organizational culture the possibility to manipulate such phenomena is attractive, but yet problematic (Smircich, 1983). While we cannot assume that single actors can fully control how groups of people conceive history, the studies cited earlier render empirical evidence that conceptions of history can be purposefully influenced.

One can easily imagine that there is a great potential of using history in a business context. Particularly to managers, influencing organizational politics by seeking legitimacy in historical circumstances can be attractive. With regard to stability, change and continuity in strategy processes, the conception of historical events is of course, decisive for the question as to whether a development is perceived as continuous or not. So far, relatively little management research has explicitly touched upon managerial use of history. Lundström's (2006) study of Ericsson, mainly focusing on the scientific use of history is one of the few exceptions. Gioia et al. (2000) paper on identity, image, and adaptive instability addresses how managers can deal with change by revising the conception of the own history prevailing in the organization. Gioia et al. (2001) further elaborate on the revision of history, claiming that change may trigger revisions of that past, which in turn facilitates further organizational change. Taking a similar stance, Chreim (2005) shows how managers evoke a sense of continuity by using historical labels while conducting change in the strategies the labels denote. In such a case, change occurs on the content level while labels remain stable. Finally, Ericson (2006) in a study of the Scandinavian consumer co-operative KF challenges linear conceptions of time. She identifies the past as a communicative partner that starts speaking when windows of opportunity open up in the strategy process. The KF case nicely illustrates how managers draw upon organizational heritage to get inspiration for their change plans and to legitimize the changes they eventually initiate.

As the previous review suggests, there are multiple ways of how and why societal or organizational actors can refer to and use the past. Karlsson (1999) offers a typology that helps disentangling five different uses of history. Each use corresponds to different needs, and has different users and functions. Karlsson's work relates to the uses of history on a national level, particularly in the former Soviet Union, but his typology can easily be transferred to the level of organizations (Table I). 
Table 1. Needs, uses, users and functions of history (Karlsson 1999: 57), my translation.

\begin{tabular}{|l|l|l|l|}
\hline Need & Use & Historian & $\begin{array}{l}\text { Verification/ } \\
\text { falsification } \\
\text { Interpretation }\end{array}$ \\
\hline Reconstruct & Existential & All & $\begin{array}{l}\text { Anchoring } \\
\text { Orientation }\end{array}$ \\
\hline Rediscover & Moral & $\begin{array}{l}\text { Broad parts of } \\
\text { the population }\end{array}$ & $\begin{array}{l}\text { Restoration } \\
\text { Rehabilitation }\end{array}$ \\
\hline $\begin{array}{l}\text { Invent } \\
\text { Construct }\end{array}$ & Ideological & $\begin{array}{l}\text { Intellectual and } \\
\text { political elites }\end{array}$ & $\begin{array}{l}\text { Rationalization } \\
\text { Legitimation }\end{array}$ \\
\hline Forget & Non-use & $\begin{array}{l}\text { Intellectual and } \\
\text { political elites }\end{array}$ & $\begin{array}{l}\text { Legitimation } \\
\text { Rationalization }\end{array}$ \\
\hline
\end{tabular}

The scientific use corresponds to the historian's critical examination and interpretation of past events. In a corporate context, the scientific use of history is typically the domain of business historians who do research on companies. Sometimes, business historians write corporate histories as commissioned work for a company, e.g. in conjunction with a corporate anniversary (Lundström, 2006). In such cases the degree of scientific ambition and rigor may of course, differ. The existential use addresses everyone's need to remember the past. It refers to the human desire of anchoring oneself in a broader context, by relating to one's origins. In organizations, the existential use of history may refer to any kind of historical reminiscence by members. A typical example might be the storytelling about the organization's past, bringing into remembrance what is perceived as important or typical for the organization. The existential use is thus particularly important in creating a sense of identity in an organization. The moral use of history implies the rehabilitation of forgotten or discredited groups, individuals and ideas. Such a use is of course, particularly obvious in the post-dictatorship context of Karlsson's (1999) study. However, also in a corporate setting, old ideas from a company's history may be brought to new life in strategic change that is legitimized through reference to the past. Strategic ideas that have fallen into oblivion or that even have been purposefully ignored for political reasons can gain new life when they are discovered anew and in that sense rehabilitated. The ideological and the non-use of history go hand in hand. Both refer to elites legitimizing and rationalizing their agendas by relating to history. In the ideological use, elites shape constructions of history that suit their purposes, while the non-use means refraining from historical reference in order to forget things that are not in line with current ideas. In an organizational context, managers are elites that can purposefully create and disseminate conceptions of the past that suit their political purposes. While all five uses of history can be expected to be found in business organizations, the moral, the ideological, and the non-use of history are particularly interesting in the context of strategy and change processes. They provide managers with an opportunity to engage in organizational politics by for instance seeking legitimacy in historical circumstances. The following analysis of the Handelsbanken and Scania cases will therefore concentrate on those three uses.

\section{Method}

The empirical study in this paper builds on in-depth case studies of two major Swedish firms, the truck manufacturer Scania and the bank Handelsbanken. Historical processes in 
organizations are by definition unique and hence, in order to be understood, they require a method that is able to capture a process in its uniqueness. In-depth case studies are particularly suited for process research since they enable the researcher to include rich contextual information in the empirical data (Pettigrew, 1997). The "depth" of the case study thus means that the generated data are not only rich in mere volume, but also stem from multiple sources, include contextual aspects and represent an extended period of time (Pettigrew, 1990). Even though case studies are highly context specific, they can serve as a basis for analytical generalization (Yin, 1989), meaning that the researcher can conceptualize and theorize based on a limited number of cases.

The studies of Handelsbanken and Scania are primarily based on 79 interviews with persons related to the two companies. Interviews were semi-structured and typically lasted for about 90 min. Most interviews were conducted with current or former strategic actors working for Scania or Handelsbanken. The majority of interviewees were thus top managers, but also middle managers and business contacts who were not employed by the two focal firms were included. In addition, I met and talked to ordinary employees while being a participant observer at meetings, training programs and various company events. Data were also generated by reviewing contemporary and historical strategy documents, company newspapers, and other written material. The interviews were transcribed and field notes were made. Based on this raw material, I developed case stories about the two companies, putting special emphasis on a number of key developments in their strategy processes. For the present paper, a number of shorter case vignettes that particularly relate to uses of history in the two companies have been extracted from the material.

\section{Uses of history at Scania and Handelsbanken}

Both Scania and Handelsbanken are old companies with a long history that provides an extensive body of material for organizational actors who want to refer back to historical events. Scania is the result of a merger between two companies, VABIS and Scania that took place in 1911. Both Scania and VABIS had been founded in the late nineteenth century and were vehicle producers. Soon the company specialized on trucks and busses as well as engines that were basically vehicle engines that were slightly modified and used for other purposes. After World War II, Scania started a rapid international expansion process and managed to establish itself as one of the few globally operating truck makers in a highly concentrated market. Though not being the largest truck maker Scania has been outperforming its competitors in terms of profitability for many years. Together, with the US truck maker Paccar, Scania had the highest return on equity among the world's truck maker during the years around the turn of the millennium (Handelsbanken Capital Markets, 2002). A review of recent annual reports from the world's leading truck makers indicates that this picture still holds today. In 2007, Scania had a return on equity of 35 percent (Scania, 2008). One of the company's characteristics is often mentioned as a key factor behind the firm's success: Scania has developed a unique product development philosophy, the so-called modular system. It implies that truck components have standardized interfaces, allowing to assemble a wide range of trucks from few components. The system gives the company a significant competitive advantage. At the same time, however, the product development philosophy also imposes restrictions on Scania's strategic options, making it difficult for the company to move into certain market segments. The modular system also makes Scania reluctant to engage in mergers and acquisitions as it would be difficult to realize major synergies with another manufacturer without spoiling modularization.

Handelsbanken was founded in 1871 as Stockholms Handelsbank. After a period of growth through mergers and acquisitions, the bank adopted a new name, Svenska Handelsbanken or just Handelsbanken in 1921. The name has remained the same since then. Today, in an industry characterized by mergers and acquisitions as well as changing brands, Handelsbanken sometimes proudly mentions that it has not changed its name since 1921. Already during the first decades of the twentieth century, Handelsbanken established itself as one of the major 
banks in the Swedish market. Owing to legal restrictions, the bank's business was primarily domestic until the late 1980s when Handelsbanken started establishing branches in the neighboring Nordic countries. Meanwhile the bank has expanded its branch network to Great Britain and is about to gain a foothold in the markets of Central and Eastern Europe. One of Handelsbanken's major goals is to attain a return on equity exceeding the average of all listed banks in countries where Handelsbanken has major operations. The bank has achieved for 36 consecutive years (Handelsbanken, 2008). One of the main turning points in the bank's history occurred in the early 1970s. Handelsbanken had been going through a less successful period, when a new managing director, Jan Wallander, entered the company and introduced a management philosophy based on a far reaching decentralization of operations. Budgeting and centralized marketing campaigns were abolished in order to make local branches more adaptive to their specific market conditions. Responsibility for all customers, including large corporate clients, was transferred to the branches where the customers where geographically located. The rationale was that local managers could make the best assessments of customers and provide them with the best service. Decisions were supposed to be made quickly without involving too many hierarchical levels. Wallander's decentralization ideas were further developed by his successors and Handelsbanken employees describe them as a major reason for the bank's success during the last 30 years. Today, virtually almost all transactions relating to a specific customer are accounted for at the responsible local branch. This also implies that most of the bank's profits are accounted for on the branch level, giving the branches a very strong position within Handelsbanken.

Both Scania and Handelsbanken are thus characterized by historically developed management philosophies that have contributed to clearly distinguishing the companies from their competitors. The strategy processes in both companies are characterized by the need to relate any strategic action to the respective management philosophy. While doing this, managers frequently refer to historical examples, using them to legitimize or delegitimize specific courses of action. In the following section of the paper we are going to look a number of brief vignettes, illustrating uses of history in both companies. In the present paper, the focus is going to be on the moral use, the ideological use and the non-use of history at Scania and Handelsbanken as these are particularly relevant from a strategy perspective. For discussions on the scientific and existential uses of history in Scania and Handelsbanken as well as for more comprehensive case descriptions, the reader can refer to Brunninge (2005).

\section{Vignette 1: Volvo's hostile takeover attempt against Scania}

In 1999, Scania was confronted with a hostile takeover attempt from its main competitor Volvo. The takeover attempt was not only questioning Scania's existence as an independent company. It also questioned Scania's historically-established success concept of working with modularized components. Merging the two companies would mean attempts to realize economies of scale between Volvo's and Scania's products. As the two companies' components were not compatible, this would imply that it was hardly possible to maintain Scania's modularization philosophy when creating shared components for the two product lines. Scania's management was from the very beginning energetically defending the company against the takeover attempt. One major argument was the assumption that mergers between truck manufacturers usually result in a loss of combined market share. Customers were believed to be reluctant to buy trucks from two brands that actually were owned by the same company. Already before 1999, analysts and investors had questioned whether the company was able to survive on its own in the long run. Already then, Scania defended its stand-alone strategy by referring to the drawbacks of mergers. Scania's Managing Director Leif Östling chose to address experiences from earlier mergers in the industry. He often summarized his lesson from historical examples in the formula $1+1 \neq 2$, meaning that it was not possible to maintain the combined market share of two companies in a merger. Particularly, the Italian truck maker Iveco was often used as an example since it was the result of several mergers and had been 
losing market share for a long time. The bad track record of Iveco was contrasted to the success of Scania that had primarily grown organically:

Mergers do not automatically imply a larger market share. Look for instance at Fiat when their boss Agnelli founded Iveco in 1975. There, $1+1 \neq 1$ hasn't become 3. It will rather be 1 soon again" (Leif $O$ " stling, interview in Scania World Bulletin 7/1990, p. 7).

Similar arguments referring to Iveco were made during the defense against Volvo's takeover attempt in 1999. Together, with other arguments against a merger with Volvo, Scania's managers communicated the Iveco case to various stakeholders like journalists, investors, customers and not least the own employees in speeches, interviews and press releases. Volvo's takeover attempt was finally warded off as the EU commission disapproved of a merger between the two companies. The Iveco case and Scania's own successful organic growth strategy were eventually not the reason why Scania managed to remain independent, but they had played an important role in management's attempts to justify the company's stand-alone strategy.

This vignette provides an example of the ideological use of history in Scania. The company's management referred to positive historical experiences of organic growth. At the same time, Scania's managing director pointed at historical industry examples of takeovers and mergers that had been unsuccessful. The aim was to legitimize Scania's stand-alone strategy and to delegitimize the idea of mergers and acquisitions. By telling the story of Iveco's failed M\&A strategy internally, Scania's management contributed to the identification of staff with the own company's strategy. Telling the story to important external stakeholders, like analysts and investors, Scania tried to gain support for the company's stand-alone strategy that was often questioned by financial analysts and the business media.

\section{Vignette 2: internet banking in Handelsbanken}

Like other financial services companies, Handelsbanken was confronted with a major technology change when the first banks started working on internet banking solutions in the 1990s. While most banks saw internet banking as a promising opportunity to rationalize their costly branch operations, many people at Handelsbanken conceived the new technology as a threat against the bank's well-established philosophy of decentralization. Since the turnaround in the early 1970s, Handelsbanken had been a decentralized bank, claiming that the local branches were the core of its operations. High autonomy over local business was given to the branch managers and being a branch manager was said to be the finest job in the bank. While the bank's Swedish competitors were trying to scale down their branch networks, Handelsbanken had successfully kept a high geographical coverage and only closed down a few branches. The decentralization philosophy was exported to new markets when the bank started to establish branch networks outside Sweden around 1990. The appearance of internet banking suddenly questioned the raison d'être of an extensive branch network and the viability of the bank's decentralization strategy. While Handelsbanken had emphasized geographical proximity to its customers the new technology seemed to make geography negligible. It was common wisdom in the banking industry that internet banking would reduce the need for local branches dramatically. People in Handelsbanken were concerned that the internet would not only lead to the closing down of many branches, but also reduce the autonomy of the remaining branches. With centralized web site distributing financial services, the local branches' possibilities of managing their own marketing efforts would be seriously reduced. As a result of these worries, Handelsbanken was unsure about how to tackle internet banking. As the other large Swedish banks introduced their internet banks, Handelsbanken was lagging about one year behind its major Swedish competitor SEB (Engholm, 1996; Hermele, 1997). A technology that was directly counter to the banks historical identity was not really legitimate in the organization:

There was resistance and hesitance towards the internet. Instinctively. A feeling that the internet was our enemy rather than something we could use and that is part of the explanation as to why we were late (Lars O Groönstedt, Managing Director, interview 2002). 
As there was hardly an option to refrain from adopting internet banking, the challenge for Handelsbanken was to find a concept for internet banking that was in line with the bank's decentralized heritage. Finally, Handelsbanken adopted a solution that was unique to the industry, at least in the countries where the bank was operating. Each of the more than 500 branches got its own web site. Customers who wanted to enter Handelsbanken via the internet had to choose their local branch when entering the bank's home page for the first time. The system then automatically stored a cookie on the customer's computer, directing him or her to the right branch when using the internet again. While all local websites shared the same layout and some transaction functions, branches had the possibility to individualize their site with information on local activities. Apart from standard products that were common to the whole bank, branch managers could decide whether to promote certain services or not. They were even able to offer customized products that did not exist in other branches to their local market. With this internet solution, Handelsbanken's management could claim that internet banking in Handelsbanken was exactly what the bank had used to be: a decentralized, branch-centered organization. The new technology was thus just a copy of the historically-established success recipe.

Also the internet banking vignette is an example of the ideological use of history. In order to legitimize the technology internally, the solution had to be perceived as continuous with regard to historically established structure of the bank. The decentralized structure of the bank served as a template for the organization of internet banking. By emphasizing how well Handelsbanken's own concept of internet banking fit into the structure with autonomous branches, the bank's management did not have to fear that the powerful branch managers or anyone else in the organization would question the new technology.

\section{Vignette 3: reviving the modular system at Scania}

As discussed above, Scania's concept of using components with standardized interfaces for achieving variety in the company's product range has become a major competitive advantage for the company. The origins of modularization date back to standardization efforts in the 1930s. The work was continued by a group of engineers around Sverker Sjöström after World War II. A central idea to modularization is that of having components in an appropriate number of performance classes. While it is generally an aim of modularization to reduce the number of components needed, standardization should not be pushed too far as this might result in components that are either too light, meaning that they risk breaking down or too heavy, resulting in high cost. The dimensioning of components needs to be adjusted to their application.

Hence, it is necessary to have a range of performance classes. Sjöström and his colleagues made extensive testing in order to determine the appropriate component dimensions for different applications. After Scania launched its first fully modularized truck generation around 1980, the modularization philosophy became taken for granted in Scania. Nobody questioned the use of it. However, as the philosophy was so strongly established, the company did not put any systematic efforts into teaching the ideas behind modularization to new employees. This turned out to become a problem when young engineers started focusing too much on standardization, reducing the number of components as much as possible and disregarding the need to adjust the dimensioning of components to different applications. As a result quality problems started increasing at Scania. When managers realized the problem, they decided to revive the heritage of modularization. On the surface, the modular system had never been questioned, but its original meaning had gotten lost along the way. The solution applied, was to document the ideas behind the modularization philosophy and to teach these ideas to Scania's employees. The basics of the modular system were summarized in a booklet where frequent reference was made to the history of the approach. Sverker Sjöström and other retired veterans from the early days of modularization appeared in the information material and Scania's magazine "Scania World" published an article on Sjöström's work: 
The development of the modular system already started between the wars and its foundations were finally laid by Sverker Sjöström. Half a century later this Scania legend is the mentor of today's Technical Director Hasse Johansson. Here, they tell the story how the modular system became one of the cornerstones in the success saga Scania (Scania World 1/2004: 18-19, caption of the picture introducing an article on modularization, my translation).

The original modularization philosophy was revived through these efforts and Scania managed to reduce its quality problems. Warranty costs that had been increasing for some years started to decline again.

The modularization vignette illustrates the moral use of history. Over time the interpretation of Scania's modular philosophy had gradually changed. In order to cope with quality problems, Scania's management decided to revive the original meaning of modularization that had partly fallen into oblivion. Scania's management thus tried to establish continuity from the early days of modularization to its application at present. The new interpretation of the modular philosophy, i.e. the young engineers' focus on standardization, was dismissed as a discontinuity. Telling the story of the modular system to new employees, emphasized its importance and created an officially authorized interpretation of modularization that was taught to organizational members in order to be preserved over time.

\section{Vignette 4: the memory of different periods in Handelsbanken's history}

Handelsbanken was founded in 1871 and a few decades later it was established as one of the major Swedish banks, a position it has retained until today. Although the bank has a long history of successful operations, it went through a severe crisis around 1970. During that time financial markets in most European countries and not least in Sweden were strictly regulated. The Swedish currency could not be freely transferred to other countries and companies were struggling with currency regulations when doing business with and making investments in foreign countries. Some were making illegal transaction to evade regulations and Handelsbanken had been involved into such transactions. When the authorities discovered the bank's involvement this resulted in a scandal seriously damaging Handelsbanken's reputation. As the bank simultaneously ran into profitability problems, Managing Director Rune Höglund resigned and was replaced by Jan Wallander in 1970. The latter introduced the decentralization of operations discussed above and managed a successful turnaround.

People at Handelsbanken, top managers as well as ordinary employees, often refer to their company's history. This may happen in everyday conversations among colleagues, in the staff magazine, internal management documents or when describing the bank and its way of doing business to customers, journalists or other stakeholders. Such storytelling almost exclusively refers to the time after Jan Wallander entered the bank and introduced his change program. It may relate to Wallander's own efforts or to stories about other Handelsbanken employees who more recently have done things that particularly reflect Wallander's ideas about running the bank. History is used ideologically in order to explain, teach and justify the management practices that are important to the company. During the interviews conducted for this study as well as at the events where I participated as an observer, Handelsbanken employees seldom made reference to the almost 100 years prior to Wallander. The few exceptions either related to the early developments after the banks foundation or the situation right before Wallander entered the bank. In the latter case, the stories usually served as a contrast to stories about Wallander's changes, illustrating how badly the bank was run before the turnaround and thus underlining how important the changes were to Handelsbanken. There was almost no reference at all to the relatively successful period from the 1930s to the 1960s. This cannot be explained by the long time lag and the resulting lack absence of eye witnesses only. Also when it comes to the early 1970s when Wallander entered the bank, there were very few people left in the organization who have personal experiences from that time. The stories from the turnaround 
have rather survived through repeated storytelling, be it in everyday conversations, in internal documents or in a number of books that Wallander has been publishing during the last 30 years. Certain aspects of Handelsbanken's history have thus been systematically preserved and communicated while other have fallen into oblivion as very little is done to keep their memory alive.

This final vignette illustrates the non-use of history. Although there is no explicit plan, probably not even a conscious idea about how Handelsbanken should refer to its past, reference to history inHandelsbanken follows a very clear pattern. The period after Wallander's entry was frequently referred to and actively used for ideological purposes, while the long history before the turnaround is practically not used at all. The consequence of this highly selective use of history was that the contrast between the pre-turnaround period and the post-turnaround period was particularly emphasized. An external observer might question whether the way of doing banking in Handelsbanken in 1965 was actually so fundamentally different from the way of doing banking in 1975. There is no doubt that Wallander introduced important changes.

Still, one might expect that there were also many similarities to the old Handelsbanken. The use and non-use of history however conjured up the image of a fundamental rupture with the entry of Jan Wallander. The frequent reference to the post-turnaround years suggested that a lot of good examples could be found in this period. The lack of reference to the period before the turnaround on the other hand suggested that those years had no value as an example for the bank of the present. The selective use and non-use of history drew a clear demarcation line between the time before and after Wallander's entry and emphasized the importance of his reforms to the bank.

\section{Discussion}

The case vignettes from Scania and Handelsbanken show that reference to history is frequently made in both companies' strategy processes. Strategists purposefully make use of history in order to affect the strategy process in line with their objectives. The three of Karlsson's (1999) uses of history that are particularly interesting for strategy processes, namely the moral use, the ideological use and the non-use of history can all be found in the vignettes. They play a central role in establishing continuity or discontinuity in the strategic development of the two firms.

\section{Establishing continuity and discontinuity by using history}

Reference to history at least implicitly constitutes a comparison between the past and the present, in some case even the envisioned future. When Scania's managers for instance told the story of Iveco's historical failures with an M\&A strategy and Scania's successful strategy of organic growth, the message was of course, that M\&As should be avoided by Scania now and in the future in order to ensure continued success for the company. Likewise, telling stories about Jan Wallander's successful turnaround in the 1970s, suggested that his management ideas should also be applied in the future. By making historical references, managers thus establish lines of continuity along which the strategy of their firm should develop. As the other side of the coin, reference to history can also point at discontinuities, emphasizing turning points in the development of a firm and showing which strategic options a firm should avoid.

In the cases of Handelsbanken and Scania, the use of history has three major functions with regard to continuity and discontinuity. The most straightforward one is establishing continuity. In the vignettes, this function can be observed in the ideological use of history. A line of development in the company's strategy is extrapolated in a continuous way, using the past as a template like when Handelsbanken transferred its idea of decentralized banking to the new internet technology. Likewise, managers can also refer to historical events that provide their strategic ideas for the future with an appropriate historical heritage, like Scania's managers supporting their organic growth strategy by pointing at the success of this strategy in the past. In the first case, ideas for the future are derived from the past while in the second case a conception of the past is constructed that supports the ideas for the future. In both examples 
strategic change happens along a continuous line of development as shown in Figure 1. Development happens in line with the basic character of the organization and in Selznick (1957) words, institutional integrity is maintained. This legitimizes strategy even if, like during Handelsbanken's introduction of internet banking, significant changes occur.

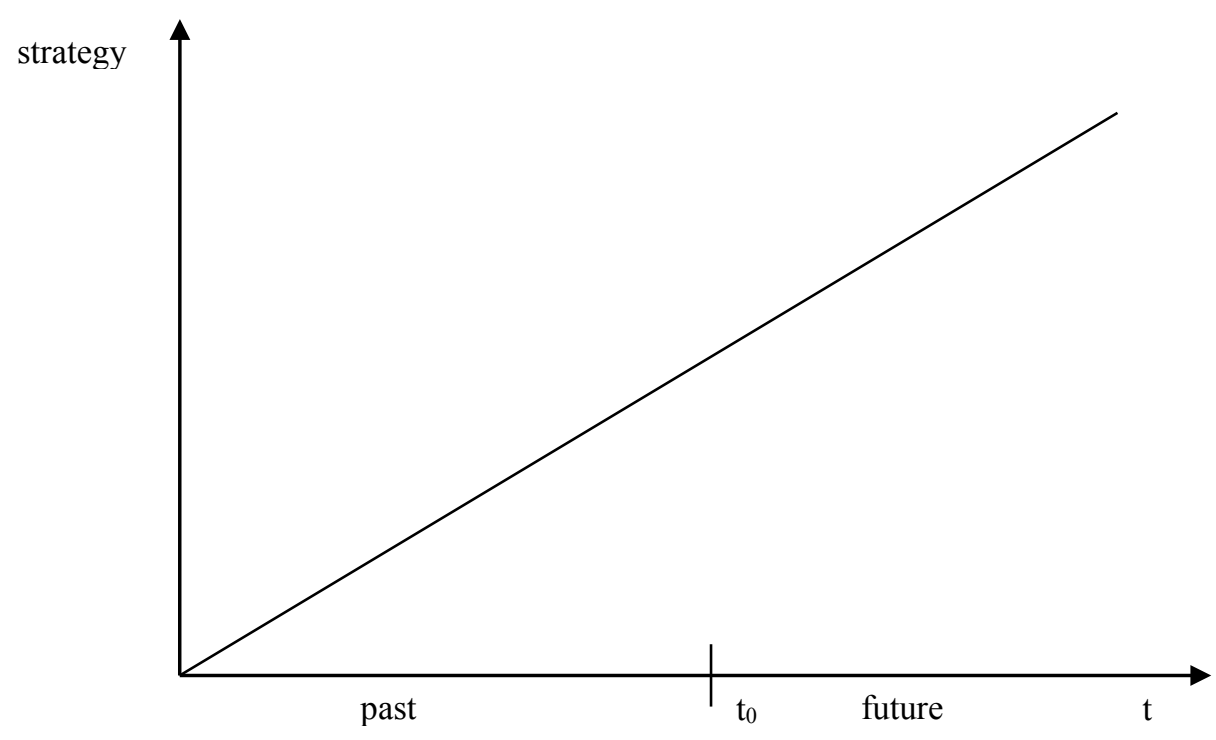

Figure 1. Establishing continuity.

Using history can also have the function of re-establishing continuity. Here, continuity does not refer to the most recent past. Rather the envisioned strategy is meant to appear like the continuous follower of a strategy back in the past of the organization, which has been abandoned for some time and that is now rediscovered. Hence, re-establishing continuity is linked to the moral use of history. In the example of Scania's modular system, the past ideas of modularization are revived by giving renewed attention to the history of their development. In contrast to this, the new interpretation of modularization is dismissed as a mistake. Strategic development has a major rupture in comparison to the immediate history while it appears as the continuous development of an earlier period (Figure 2). By pointing at continuity in a long-term perspective, the major short-term change is legitimized. Rather than being perceived as a destroyer of institutional integrity, the change stands out as its defender since the supposedly original character of the organization is restored. 


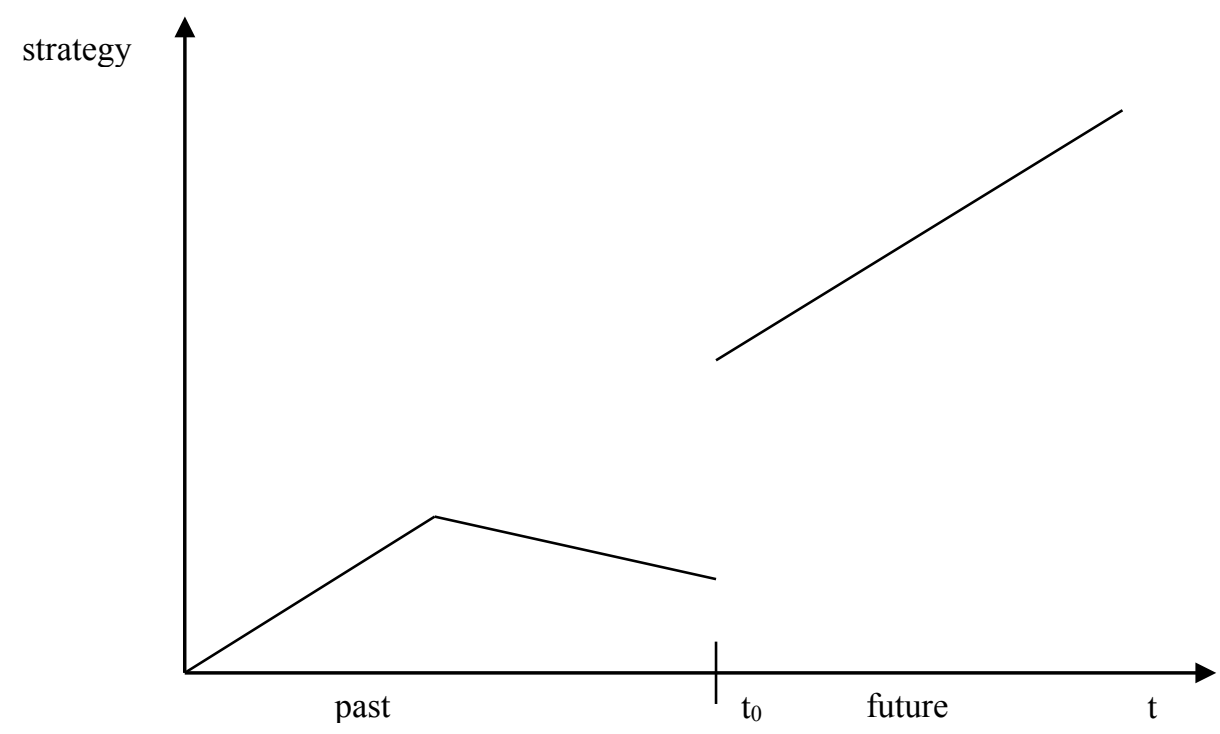

Figure 2. Re-establishing continuity.

Finally, the use - or more precisely the non-use - of history can also have the function of establishing discontinuity. By consciously or unconsciously refraining from reference to a specific period in the history of their organization, that period appears as irrelevant as a point of reference for current and future strategy making. It appears at best, if it is reflected upon at all, as an example of bad management practice. Here, discontinuity is established through the nonuse of history, like in the example of Handelsbanken largely refraining from historical reference to the time before Wallander. In that example, continuity with regard to the most recent history, i.e. the post-turnaround years was desired and emphasized. On the other hand continuity with regard to the history before had little importance (Figure 3).

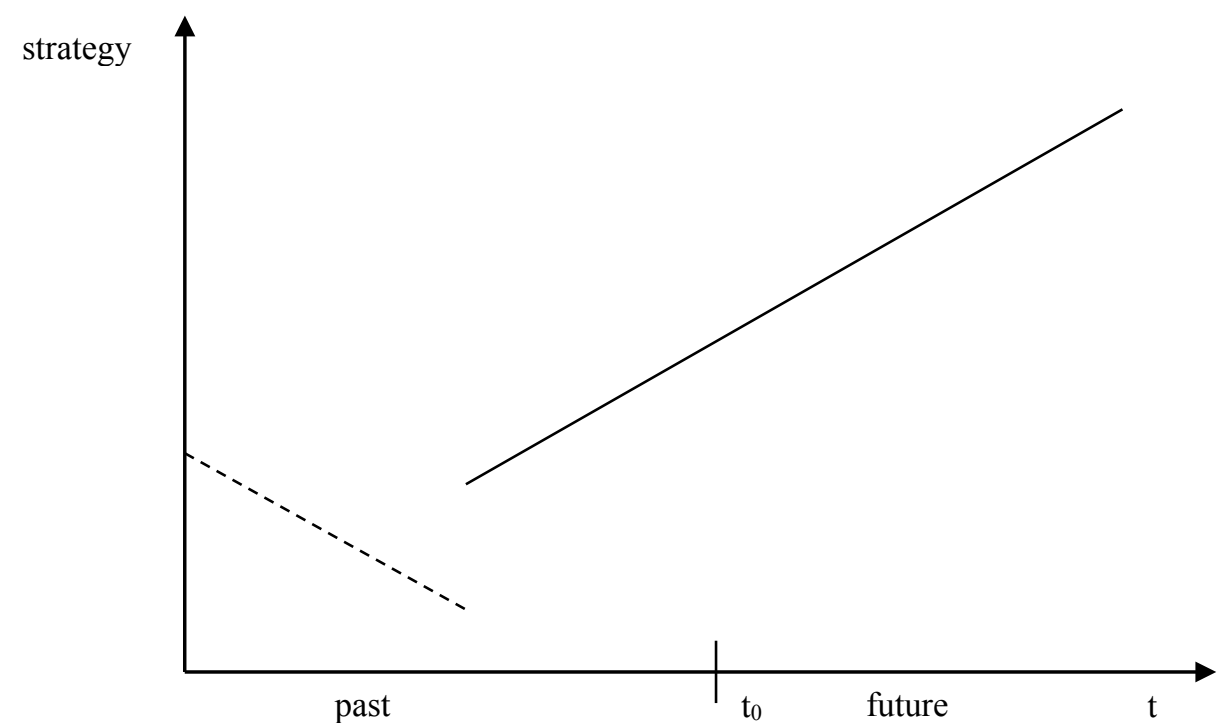

Figure 3. Establishing discontinuity. 
The memory of these years was weak as signified by the dotted line in the picture. In cases of establishing discontinuity, strategists refrain from maintaining institutional integrity with regard to at least parts of organizational history. The rupture in strategic development is desired and even emphasized in order to legitimize discontinuous change.

\section{Conclusions}

This paper started out by suggesting that an interpretive view on organizational history might contribute to a better understanding of organizational and strategic change. A basic idea was that organizational members in various ways refer to the past and sometimes purposefully use organizational history to influence change processes. This includes that conceptions of the past can change over time as organizational members reconstruct them in order to fit their strategic agendas.

The cases of Scania and Handelsbanken support these assumptions. In both cases, organizational interest in history goes clearly beyond mere reminiscence of a time that has passed and never will come back. Three different uses of history, the moral use, the ideological use, and the non-use of history play key roles in organizational strategy. In this context, history becomes a powerful resource that can be instrumentalized by actors to legitimize or delegitimize possible strategic routes for the future. Strategic ideas are most easily legitimized by portraying them as the continuous followers of a successful strategy in organizational history. The historical example may either be a strategy the company is still using or a past strategy that has fallen into oblivion and can be revived. Organizational actors use history selectively. In this sense the past becomes a quarry as described by Schulze (1987). Actors pick and refer to those parts of history that best suit their purposes, either to serve as a positive forerunner of their own ideas or as a terrible warning not to choose an option they disapprove of.

A further important conclusion of the Scania and Handelsbanken cases is that history is not necessarily a source of organizational inertia. History as organizational members perceive it is not fixed. Conceptions of history can be altered. Moreover, the past of an organization comprises so many different aspects that not all of them are equally salient in people's memories. This provides scope for constructing and reconstructing organizational history in ways that promote change. What strategists need to do is to make changes appear as continuous in order to keep the institutional integrity (Selznick, 1957) of the organization intact. As long as a sense of continuity in strategic change is maintained, it is relatively likely that changes will be accepted.

Generally, the present paper shows that the organizational use of history is an interesting and fruitful perspective for understanding organizations in general and organizational stability and change in particular. We need more empirical work in this still under researched area. Of course, the present study is not without limitations. Both Scania and Handelsbanken are old companies that show a particular interest in their own history. The past is often referred to and this fact in itself makes it probably easier for organizational members to use and instrumentalize history. There are certainly organizations where history is less frequently referred to. It would therefore be an interesting question for further research to find out the reasons why history is more frequently referred to in some organizations and less frequently in others. How common is the use of history in young organizations? Is history used in other ways in young organizations than in old ones? Answers to these questions might provide us with interesting insights in the field of organizational change management.

\section{References}

Albert, S. and Whetten, D.A. (1985), "Organizational identity", Research in Organizational Behavior, No. 7, pp. 263-95.

Aronsson, P. (2004), Historiebruk: Att använda det förflutna, Studentlitteratur, Lund. 
Barney, J.B. (1991), "Firm resources and sustained competitive advantage", Journal of Management, Vol. 17 No. 1, pp. 99-120.

Brunninge, O. (2005), "Organisational self-understanding and the strategy process. Strategy dynamics in Scania and Handelsbanken", JIBS Dissertation Series, No. 027, Jönköping International Business School, Jönköping.

Chandler, A.D. Jr (1962), Strategy and Structure: Chapters in the History of the Industrial Enterprise, MIT Press, Cambridge, MA.

Chandler, A.D. Jr (1977), The Visible Hand, The Belknap Press of Harvard University Press, Cambridge, MA.

Chreim, S. (2005), "The continuity-change duality in narrative texts of organizational identity", Journal of Management Studies, Vol. 42 No. 3, pp. 567-93.

Clark, P. and Rowlinson, M. (2004), "The treatment of history in organisation studies: towards a 'historic turn'?", Business History, Vol. 46 No. 3, pp. 331-52.

Cohen, M.D. and March, J.G. (1986), Leadership and Ambiguity, 2nd ed., Harvard Business School Press, Boston, MA.

David, P.A. (1985), "Clio and the economics of QWERTY", American Economic Review Proceedings, Vol. 75 No. 2, pp. 332-7.

Engholm, A. (1996), "SE-Banken o"ppnar kontor pa internet", Computer Sweden, Vol. 3, p. 1996.

Ericson, M. (2006), "Exploring the future, exploiting the past", Journal of Management History, Vol. 12 No. 2, pp. 121-36.

Frankelius, P. (1999), Pharmacia \& Upjohn. Erfarenheter från ett världsföretags utveckling, Liber Ekonomi, Malmö.

Freeland, R.F. (2001), The Struggle for Control of the Modern Corporation: Organizational Change at General Motors, 1924-1970, Cambridge University Press, Cambridge.

Gioia, D. and Chittipeddi, K. (1991), "Sensemaking and sensegiving in strategic change initiation", Strategic Management Journal, Vol. 12 No. 6, pp. 433-48.

Gioia, D.A., Corley, K.G. and Fabbri, T. (2001), "Revising the past (while thinking in the future perfect tense)", Journal of Organizational Change Management, Vol. 15 No. 6, pp. 622-34.

Gioia, D., Schultz, M. and Corley, K.G. (2000), "Organizatioal identity, image, and adaptive instability", Academy of Management Review, Vol. 25 No. 1, pp. 63-81.

Handelsbanken (2008), Annual Report 2007, Handelsbanken, Stockholm.

Handelsbanken Capital Markets (2002), Company Report. Scania: For Demanding Investors, Handelsbanken Capital Markets, Stockholm.

Hannan, M.T. and Freeman, J. (1977), "The population ecology of organizations", American Journal of Sociology, Vol. 82 No. 5, pp. 929-63.

Hatch, M.J. and Schultz, M. (1997), "Relations between organizational culture, identity and image", European Journal of Marketing, Vol. 31 Nos 5/6, pp. 356-65.

Hermele, B. (1997), "Svenska banker öppnar dörren för säker handel på internet", Dagens Industri, 10 October.

Hobsbawm, E. and Ranger, T. (1992), The Invention of Tradition, Cambridge University Press, Cambridge.

Jeismann, K-E. (1979), "Geschichtsbewusstsein", in Bergmann, K., Kuhn, A., Rüsen, J. and Schneider, G. (Eds), Handbuch der Geschichtsdidaktik, Band 1, Schwann, Düsseldorf, pp. 4245.

Jensen,B.E. (1997),"Historiemedvetande - begreppsanalys, samha"1lsteori, didaktik", in Karlegärd, C. and Karlsson, K-G. (Eds), Historiedidaktik, Studentlitteratur, Lund, pp. 49-81.

Johnson, G. (1987), Strategic Change and the Management Process, Basil Blackwell, Oxford.

Karlsson, K-G. (1999), Historia som vapen. Historiebruk och Sovjetunionens upplösning 19851995, Natur och Kultur, Stockholm.

Karlsson, K-G. (2003), "The Holocaust as a problem of historical culture. Theoretical and analytical challenges", in Karlsson, K-G and Zander, U. (Eds), Echoes of the Holocaust. Historical Cultures in Contemporary Europe, Nordic Academic Press, Lund, pp. 9-57.

Kieser, A. (1987), "From asceticism to administration of wealth: medieval monasteries and the pitfalls of rationalization", Organization Studies, Vol. 8 No. 2, pp. 103-23. 
Kieser, A. (1989), "Organizational, institutional, and societal evolution: medieval craft guilds and the genesis of formal organizations", Administrative Science Quarterly, Vol. 34, pp. 54064.

Kieser, A. (1994), "Why organization theory needs historical analyses - and how this should be performed", Organization Science, Vol. 5 No. 4, pp. 608-20.

Kimberly, J.R. (1987), "The study of organization: toward a biographical perspective", in Lorsch, J.W. (Ed.), Handbook of Orgnaizational Behavior, Prentice-Hall, Englewood Cliffs, NJ, pp. 223-37.

Kimberly, J.R. and Bouchikhi, H. (1995), "The dynamics of organizational development and change: how the past shapes the present and constrains the future", Organization Science, Vol. 6 No. 1, pp. 9-18.

Lundström, B. (2006), "Grundat 1876. Historia och företagsidentitet inom Ericsson", doctoral dissertation, Royal Institute of Technology, Stockholm.

Melander, A. (1997), "Industrial wisdom and strategic change. The Swedish pulp and paper industry 1945-1990", doctoral dissertation, Jönköping International Business School, Jönköping.

Melander,A. (2005), "Industry-wide belief structures and strategic behaviour. The Swedish pulp and paper industry 1945-1980", Scandinavian Economic History Review, Vol. 53 No. 1, pp. 91-118.

Melin, L. (1998), "Strategisk förändring: om dess drivkrafter och inneboende logik", in Czarniawska, B. (Ed.), Organisationsteori på svenska, Liber, Malmö, pp. 61-85.

Nelson, R.R. and Winter, S.G. (1982), An Evolutionary Theory of Economic Change, Harvard University Press, Cambridge, MA.

Nora, P. (1998), Zwischen Geschichte und Gedächtnis, Fischer Tachenbuch Verlag, Frankfurt am Main.

Normann, R. (1975), Skapande färetagsledning, Bonniers, Stockholm.

The Oxford English Dictionary (1989), Clarendon Press, Oxford.

Pettigrew, A.M. (1985), The Awakening Giant: Continuity and Change in ICI, Blackwell, Oxford.

Pettigrew, A.M. (1990), "Longitudinal field research on change: theory and practice", Organization Science, Vol. 1 No. 3, pp. 267-92.

Pettigrew, A.M. (1997), "What is processual analysis?", Scandinavian Journal of Management, Vol. 13 No. 4, pp. 337-48.

Reichel, P. (2005), "Auschwitz", in François, E. and Schulze, H. (Eds), Deutsche Erinnerungsorte, Bundeszentrale für politische Bildung, Schriftenreihe Band 475, Bonn, pp. 309-31.

Rhenman, E. (1973), Organization Theory for Long-range Planning, Wiley, London.

Scania (2008), Annual Report 2007, Scania CV AB, Södertälje.

Schulze, H. (1987), Wir sind, was wir geworden sind, Pieper, München.

Selznick, P. (1957), Leadership in Administration, Harper \& Row, New York, NY.

Smircich, L. (1983), "Concepts of culture and organizational analysis", Administrative Science Quarterly, Vol. 28, pp. 339-58.

Teece, D., Pisano, G. and Shuen, A. (1997), "Dynamic capabilities and strategic management", Strategic Management Journal, Vol. 18 No. 7, pp. 509-33.

Trenter, C. (2000), “'And now - imagine she's white' - postkolonial historieskrivning”, in Aronsson, P. (Ed.), Makten over minnet. Historiekultur i förändring, Studentlitteratur, Lund, pp. 50-62.

Üsdiken, B. and Kieser, A. (2004), "Introduction: history in organisation studies", Business History, Vol. 46 No. 3, pp. 321-30.

Wernerfelt, B. (1984), "A resource-based view of the firm", Strategic Management Journal, Vol. 5, No. 2, pp. 171-80.

Yin, R.K. (1989), Case Study Research. Design and Methods, Sage, Newbury Park, CA.

Zander, U. (1997), "Historia och identitetsbildning", in Karlegärd, C. and Karlsson, K-G. (Eds), Historiedidaktik, Studentlitteratur, Lund, pp. 82-114. 
Zander, U. (2001), Fornstora dagar, moderna tider. Bruk av och debatter om svensk historia från sekelskifte till sekelskifte, Nordic Academic Press, Lund. 